\title{
Multidisciplinary Perspectives of Current Approaches and Clinical Gaps in the Management of Hyperphosphatemia
}

\author{
Michel Vallée (D) \\ Jordan Weinstein ${ }^{2}$ \\ Marisa Battistella ${ }^{3}$ \\ Roxanne Papineau ${ }^{4}$ \\ Dianne Moseley ${ }^{5}$ \\ Gordon Wong ${ }^{6}$
}

'Université de Montréal - Hôpital Maisonneuve-Rosemont, Montréal, Québec, Canada; ${ }^{2}$ Division of Nephrology, St Michael's Hospital, University of Toronto, Toronto, Ontario, Canada; ${ }^{3}$ University Health NetworkToronto General Hospital, Toronto, Ontario, Canada; ${ }^{4}$ Institut Universitaire de Cardiologie et de Pneumologie de Québec, Québec City, Québec, Canada; ${ }^{5}$ Trillium Health Partners, Mississauga, Ontario, Canada; ${ }^{6}$ Trillium Health Partners, Credit Valley Nephrology, Mississauga, Ontario, Canada
Correspondence: Gordon Wong Trillium Health Partners, Credit Valley Nephrology, 2300 Eglinton Ave. West Suite \#50I, Mississauga, Ontario, L5M 2V8, Canada

Email gwong1030@gmail.com

\begin{abstract}
Population-based studies have shown that most patients with advanced chronic kidney disease (CKD) do not have optimal phosphate levels. Meta-analyses suggest that there is a morbidity and mortality benefit associated with the lowering of serum phosphate levels. However, to date there is no conclusive evidence from randomized controlled trials (RCTs) that lowering serum phosphate levels reduces the risk of morbidity and mortality. However, hyperphosphatemia may pose a risk to patients and treatment should be considered. We therefore sought to conduct a multidisciplinary review to help guide clinical decision-making pending results of ongoing RCTs. Restricting dietary phosphate intake is frequently the first step in the management of hyperphosphatemia. Important considerations when proposing dietary restriction include the patient's socioeconomic status, lifestyle, dietary preferences, comorbidities, and nutritional status. While dietary phosphate restriction may be a valid strategy in certain patients, serum phosphate reductions achieved solely by limiting dietary intake are modest and should be considered in conjunction with other interventions. Conventional dialysis is also typically insufficient; however phosphate removal may be augmented by increased frequency or duration of dialysis, or through enhanced methods such as hemodiafiltration. Phosphate binders have been shown to reduce absorption of dietary phosphate and lower serum phosphate levels. There are several phosphate binders available, and while they all lower phosphate levels to variable degrees, they differ with respect to their pill burden, potential to induce or exacerbate vascular calcification or ectopic calcification, tissue accumulation, safety, and tolerability. The widespread treatment of hyperphosphatemia requires convincing data from RCTs to ascertain whether lowering serum phosphate levels improves patient-important outcomes, as well as the optimal method and degree of phosphate control. In the interim, the decision and approach used to treat hyperphosphatemia should be based on the best available data, as well as patient needs and clinical judgment.
\end{abstract}

Keywords: chronic kidney disease, nutrition, phosphate, phosphate binders

\section{Introduction}

Significant controversy exists about whether and how best to treat hyperphosphatemia. While several meta-analyses and retrospective cohort studies have suggested that hyperphosphatemia is associated with an increased relative risk of hospitalization, cardiovascular events, and death, evidence from randomized controlled trials (RCTs) demonstrating that lowering serum phosphate levels improves these outcomes is not yet available. ${ }^{1-5}$

However, hyperphosphatemia is common in the later stages of chronic kidney disease $(\mathrm{CKD})$ when kidney function is significantly impaired. ${ }^{6-8}$ Documented 
symptoms and clinical complications of hyperphosphatemia include pruritus, bone disease, and calciphylaxis. ${ }^{9}$ Clinicians must therefore use the best data available to continue to manage patients and the consequences of hyperphosphatemia. To facilitate clinical decision-making pending the results of ongoing RCTs, we conducted a multidisciplinary review of the existing data and examined clinical considerations and care gaps in the treatment of hyperphosphatemia.

\section{Materials and Methods}

Information was gathered by a PubMed search of recent publications and landmark studies on the management of hyperphosphatemia, as well as national and international societies' guidelines. We have attempted to provide a comprehensive review of the available data using numerous diverse studies and extensive review of the literature.

\section{Impact of Hyperphosphatemia on Morbidity and Mortality}

Several retrospective studies have observed an association between hyperphosphatemia and morbidity and mortality in patients with CKD. ${ }^{8,10-12}$

An analysis of retrospective data from 40,538 hemodialysis patients by Block et al in 2004 found that serum phosphate concentrations $>1.61 \mathrm{mmol} / \mathrm{L}(>5.0 \mathrm{mg} / \mathrm{dL})$ were associated with an increased relative risk of death. ${ }^{10}$ Similarly, survival models of data from 25,588 patients on hemodialysis in DOPPS I, DOPPS II, or DOPPS III suggest that the lowest mortality risk is in patients with phosphate $1.16-1.61 \mathrm{mmol} / \mathrm{L}$ $(3.6-5.0 \mathrm{mg} / \mathrm{dL})$, whereas the greatest risk of mortality is when phosphate levels are $>2.26 \mathrm{mmol} / \mathrm{L}(>7.0 \mathrm{mg} / \mathrm{dL}) .{ }^{11}$ Likewise, in patients with CKD not on chronic dialysis, serum phosphate levels $>1.13 \mathrm{mmol} / \mathrm{L}$ ( $>3.5 \mathrm{mg} / \mathrm{dL}$ ) have been associated with a significantly increased risk of death, with the mortality risk increasing linearly with each subsequent $0.16 \mathrm{mmol} / \mathrm{L}(0.5 \mathrm{mg} /$ $\mathrm{dL}$ ) increase in phosphate levels. ${ }^{8}$

Hyperphosphatemia has also been significantly associated with all-cause, cardiovascular, and fracture-related hospitalization, ${ }^{10}$ as well as with cardiovascular events and mortality. ${ }^{12}$

\section{Outcomes Associated with Lowering Phosphate Levels}

Phosphate binders have been shown to significantly lower serum phosphate in patients with CKD. ${ }^{13}$ However, secondary analyses of Medicare claims data in the Dialysis Clinical Outcomes Revisited (DCOR) trial found that lowering phosphate levels with sevelamer versus calciumbased phosphate binders does not affect overall mortality, cause-specific mortality, morbidity, or cause-specific hospitalization in patients on hemodialysis. ${ }^{14}$ While other data suggest that lowering phosphate levels improves morbidity and mortality, that data is retrospective in nature, occasionally conflicting, and inconclusive. ${ }^{1-5}$

One systematic review noted a trend towards a decrease in all-cause mortality with non-calcium-based versus calcium-based phosphate binders (relative risk [RR] $0.68 ; 95 \%$ CI $0.41-1.11$ ) but no statistically significant difference in cardiovascular mortality and coronary artery calcification. ${ }^{1}$ An updated meta-analysis later showed that patients assigned to non-calcium-based phosphate binders had a $22 \%$ reduction in all-cause mortality compared with those assigned to calcium-based phosphate binders. ${ }^{5}$

Similarly, another systematic review and network metaanalysis of patients with bone-mineral disorders randomized to receive calcium (as calcium acetate, calcium citrate or calcium carbonate), non-calcium-based binders (sevelamer hydrochloride, sevelamer carbonate, lanthanum carbonate, $\mathrm{SFOH}$, and ferric citrate), phosphate restricted diet, placebo, or no treatment, found a higher rate of mortality with calcium than either sevelamer (RR, 1.89 [95\% CI, 1.02 to 3.50]) or non-calcium-based binders (RR, 1.76 [95\% CI, 1.21 to 2.56 ). There was also a higher rate of hospitalization, although non-significant, with calcium than non-calciumbased binders (RR, 1.293 [95\% CI, 0.94 to 1.74]). ${ }^{2}$

A more recent systematic review comparing sevelamer or lanthanum with other phosphate binders in CKD reported that sevelamer was associated with a nonsignificant reduction in mortality, but significantly lower hospitalization rates and hypercalcemia compared with calcium-based binders. In contrast, lanthanum and iron-based binders did not show superiority for any clinically relevant outcomes. This analysis also found that outcomes, such as cardiac events, fractures, calciphylaxis, and health-related quality of life (HRQOL) remain understudied. $^{3}$

A Cochrane review of 104 clinical trials with 13,744 patients with CKD also underscored the need for additional evidence of the clinical impact of lowering phosphate levels. The analysis found that in patients with CKD stage 5 on dialysis, sevelamer may lower death (all causes) compared to calcium-based binders and may result in less treatment-related hypercalcemia. However, no clinically important benefits of any phosphate binder on cardiovascular death, myocardial infarction, stroke, fracture, or coronary artery calcification were found. In patients with 
CKD stages 2-5, the effects of sevelamer, lanthanum, and iron-based phosphate binders on cardiovascular, vascular calcification, and bone outcomes compared to placebo or usual care, were also uncertain. ${ }^{4}$

\section{Prospective and Ongoing RCTs}

The Two phosphAte taRGets in End-stage renal disease Trial (TARGET) was a pilot RCT that aimed to assess whether lowering phosphate concentrations with binders improves patient-important outcomes. Hemodialysis patients receiving a calcium-based phosphate binder were randomized to an intensive phosphate goal of $0.75-1.50$ $\mathrm{mmol} / \mathrm{L}(2.3-4.7 \mathrm{mg} / \mathrm{dL})$ or a liberalized target of 2.00 $2.50 \mathrm{mmol} / \mathrm{L}(6.2-7.8 \mathrm{mg} / \mathrm{dL})$. The mean serum phosphate level reported at 26 weeks was $1.46 \mathrm{mmol} / \mathrm{L}(4.5 \mathrm{mg} / \mathrm{dL})$ in the intensive group and $1.95 \mathrm{mmol} / \mathrm{L}(6.1 \mathrm{mg} / \mathrm{dL})$ in the liberalized group. There were no statistically significant differences between groups in the risk of hypercalcemia, hypocalcemia, parathyroidectomy, or major vascular events. While these findings suggest that it is feasible to achieve and maintain a difference in serum phosphate levels by titrating the dose of phosphate binder, a larger trial is needed to determine if targeting a lower serum phosphate level improves clinical and patient-related outcomes. $^{15}$

To this end, the HiLo and Pragmatic Randomized Trial of High Or Standard PHosphAte Targets in End-stage Kidney Disease (PHOSPHATE) RCTs are being conducted. ${ }^{16,17}$ HiLo is an open-label, multicenter, RCT of $\sim 4400$ patients with end-stage kidney disease (ESKD) undergoing maintenance hemodialysis. The primary objective of the HiLo trial is to test whether less stringent control of serum phosphate to $>2.10 \mathrm{mmol} / \mathrm{L}(>6.5 \mathrm{mg} /$ dL) will yield a reduction in the hierarchical composite outcome of time to all-cause mortality and all-cause hospitalization compared with serum phosphate targets of $<1.77 \mathrm{mmol} / \mathrm{L}(<5.5 \mathrm{mg} / \mathrm{dL})$. The trial will also assess whether compared to strict phosphate control, less stringent control will reduce the risk of all-cause mortality, enhance markers of diet and nutrition, and improve HRQOL. ${ }^{16}$ The PHOSPHATE trial will evaluate whether compared to high levels, lowering phosphate levels reduces mortality or major events due to heart disease, improves physical health, and is cost-effective. An estimated 3600 ESKD patients receiving dialysis will be randomized either to intensive $(\leq 1.50 \mathrm{mmol} / \mathrm{L}[\leq 4.7 \mathrm{mg} / \mathrm{dL}])$ or liberalized $(2.0-2.5 \mathrm{mmol} / \mathrm{L}[6.4-7.8 \mathrm{mg} / \mathrm{dL}])$ serum phosphate levels. $^{17}$
However, both trials are still recruiting, and estimated study completion dates are in April 2023 for the HiLo trial and December 2025 for the PHOSPHATE trial. ${ }^{16,17}$ In the interim, clinicians must use the best data available to select a strategy to manage hyperphosphatemia and its consequences in their patients.

\section{Strategies to Manage Hyperphosphatemia}

Common strategies to manage hyperphosphatemia include dietary phosphate restriction, the dialytic removal of phosphate, and the use of phosphate binders. ${ }^{18}$

\section{Restriction of Dietary Phosphate Intake}

Restricting dietary phosphate intake is frequently the first step in the management of hyperphosphatemia. Important factors to consider when proposing dietary phosphate restriction include the source and bioavailability of the phosphate. $^{19}$

Common sources of dietary phosphate include 1) organic phosphate in plant foods; 2) organic phosphate in animal protein; and 3) inorganic phosphate used to prolong shelf-life and to improve taste and texture in processed foods. ${ }^{20}$ However, the amount of phosphate present does not necessarily reflect phosphate uptake as bioavailability varies according to the form and food source. Inorganic phosphate from food additives has an 80-100\% bioavailability, compared with organic phosphate from plant foods and animal protein which have a $20-40 \%$ and $40-60 \%$ bioavailability, respectively. Moreover, inorganic phosphate is not protein-bound and so dissociates easily in the gut lumen, is readily absorbed across the intestinal wall, and therefore has the most impact on hyperphosphatemia. ${ }^{18,20}$ Thus, inorganic phosphates are often underappreciated as a source of dietary phosphate. ${ }^{20}$

Drugs that are commonly prescribed to patients on dialysis may also be an unrecognized source of phosphate (Table 1). ${ }^{21}$ Other drugs may also contain phosphate and information on their phosphate content is not always available.

The National Kidney Foundation's Kidney Disease Outcomes Quality Initiative (KDOQI) Clinical Practice Guideline for Nutrition in CKD: 2020 Update and the Kidney Disease: Improving Global Outcomes (KDIGO) 2017 Clinical Practice Guideline Update for the Diagnosis, Evaluation, Prevention, and Treatment of CKD-mineral and bone disorder (CKD-MBD) recommend limiting dietary phosphate intake in the treatment 
Table I Common Medications High in Phosphate

\begin{tabular}{|c|c|}
\hline Medication and Dosage (mg) & Phosphate Content (mg)* \\
\hline \multicolumn{2}{|l|}{ Paroxetine } \\
\hline $10.0 \mathrm{mg}$ & $17.1-147.9 \mathrm{mg}$ \\
\hline $20.0 \mathrm{mg}$ & $55.8-295.8 \mathrm{mg}$ \\
\hline $30.0 \mathrm{mg}$ & $443.7 \mathrm{mg}$ \\
\hline $40.0 \mathrm{mg}$ & $111.5 \mathrm{mg}$ \\
\hline \multicolumn{2}{|l|}{ Amlodipine } \\
\hline $2.5 \mathrm{mg}$ & $20.9-29.1 \mathrm{mg}$ \\
\hline $5.0 \mathrm{mg}$ & $3.8-82.8 \mathrm{mg}$ \\
\hline $10.0 \mathrm{mg}$ & $7.9-165.6 \mathrm{mg}$ \\
\hline \multicolumn{2}{|l|}{ Lisinopril } \\
\hline $5.0 \mathrm{mg}$ & $3.6-18.4 \mathrm{mg}$ \\
\hline $10.0 \mathrm{mg}$ & $21.4-32.6 \mathrm{mg}$ \\
\hline $20.0 \mathrm{mg}$ & $7.4-30.7 \mathrm{mg}$ \\
\hline $30.0 \mathrm{mg}$ & $27.4 \mathrm{mg}$ \\
\hline $40.0 \mathrm{mg}$ & $26.2-30.8 \mathrm{mg}$ \\
\hline \multicolumn{2}{|l|}{ Sitagliptin } \\
\hline $25.0 \mathrm{mg}$ & $7.3 \mathrm{mg}$ \\
\hline $50.0 \mathrm{mg}$ & $13.2 \mathrm{mg}$ \\
\hline \multicolumn{2}{|l|}{ Acetaminophen } \\
\hline $8 \mathrm{mg}$ Codeine & $60 \mathrm{mg}$ \\
\hline 15 mg Codeine & $60 \mathrm{mg}$ \\
\hline $30 \mathrm{mg}$ Codeine & $60 \mathrm{mg}$ \\
\hline
\end{tabular}

Notes: *Variations in phosphate content occur based on manufacturer; adapted from Li J, Wang L, Han M, et al. The role of phosphate-containing medications and low dietary phosphorus-protein ratio in reducing intestinal phosphorus load in patients with chronic kidney disease. Nutr Diabetes. 2019;9(I): $14{ }^{84}$

of hyperphosphatemia and considering the bioavailability of phosphate in different foods. ${ }^{22,23}$

However, foods that do not contain additives are often more costly than their additive-containing equivalents and socioeconomic factors (eg, age, education level, income, employment status) have been shown to influence adherence to a low-phosphate diet. $^{20,24}$ Dialysis patients in particular acknowledge that dietary restriction is challenging and longer dialysis vintage is associated with a lower rate of dietary adherence. ${ }^{20}$

In addition, phosphate-restricted diets may result in impaired nutritional status in patients on dialysis. As highprotein foods are an important source of phosphate, imposing dietary phosphate restriction is commonly associated with a reduction in protein intake. This has been linked to malnutrition, reduced quality of life, protein-energy wasting, and increased mortality. ${ }^{25-28}$
Therefore, patient education is critical to the successful implementation of a phosphate restriction diet. Effective education should involve a multidisciplinary approach and include a discussion of the role of phosphate in disease and the importance of adherence to dietary recommendations. Suggestions for foods with minimal inorganic phosphate content or additives, low phosphate-to-protein ratios, and adequate protein content should also be offered. Patient education may also include a discussion of "hidden" phosphate content in additives such as modified starches or baking powder. ${ }^{20}$ In addition, as boiling causes demineralization of food, thus reducing phosphate content, boiling should be recommended as the preferred cooking technique. Patients should be advised that the degree of mineral loss is proportional to the amount of boiling water that is used, the size of the pieces, the cooking time, and the absence of the peel for plants. ${ }^{29}$

Educational initiatives should involve patients' families and friends and be tailored to patients' lifestyle, environment, career, ethnicity, cultural background, and socioeconomic status. $^{20}$ The Phosphate Pyramid is an example of a useful tool that can be used with the patient to present the phosphate load of various foods (Figure 1). ${ }^{29}$

\section{Phosphate Removal by Dialysis}

Elimination of phosphate by dialysis is another cornerstone in the management of hyperphosphatemia. Phosphate clearance by hemodialysis is dependent on blood and dialysate flow rate, dialyzer membrane surface area, and ultrafiltration volume. ${ }^{30}$ The dialytic removal of phosphate is approximately $300 \mathrm{mg} /$ day in patients on peritoneal dialysis and approximately $350 \mathrm{mg} /$ day in hemodialysis patients on a 3x-weekly regimen. ${ }^{31,32}$ However, phosphate intake commonly averages $1000-2000 \mathrm{mg} /$ day, of which approximately $60 \%$ is absorbed. 9,33 Thus, conventional hemodialysis or peritoneal dialysis are insufficient to achieve a neutral phosphate balance.

Phosphate removal by dialysis may be enhanced by increased frequency and duration. Data suggest that nocturnal hemodialysis more effectively lowers serum phosphate than conventional hemodialysis (from 1.78 to 1.44 $\mathrm{mmol} / \mathrm{L}[5.5$ to $4.5 \mathrm{mg} / \mathrm{dL}])^{34,35}$ In the Nocturnal trials, patients receiving $6 \mathrm{x}$-weekly sessions experienced a relative decrease of $0.40 \mathrm{mmol} / \mathrm{L}(1.2 \mathrm{mg} / \mathrm{dL})$ in mean serum phosphate compared with patients receiving $3 \mathrm{x}-$ weekly sessions. Similarly, the Daily trial demonstrated that patients receiving $6 \mathrm{x}$ weekly sessions experienced a relative decrease of $0.15 \mathrm{mmol} / \mathrm{L}(0.5 \mathrm{mg} / \mathrm{dL})$ in mean 


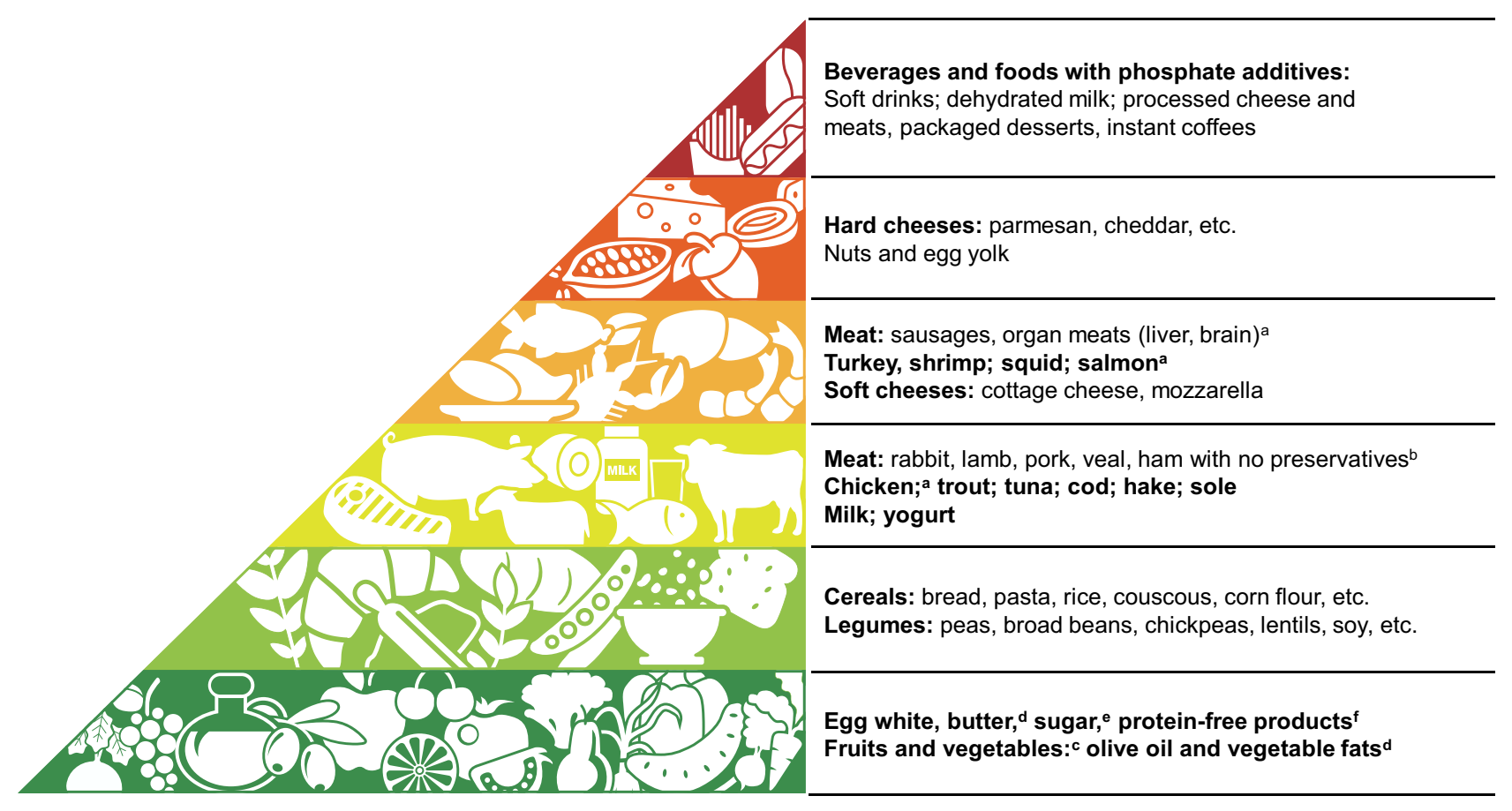

Figure I The Phosphate Pyramid.

Notes: Foods are grouped into 6 levels based on phosphate content, phosphate-to-protein ratio, and phosphate bioavailability. ${ }^{a}$ Foods with unfavorable phosphate to protein ratio (>12 mg/g); ${ }^{b}$ foods with favorable phosphate to protein ratio $(<12 \mathrm{mg} / \mathrm{g})$; c fruits and vegetables must be used with caution in dialysis patients to avoid excessive potassium load; ${ }^{d}$ fats must be limited in overweight/obese patients, to avoid excessive energy intake; ${ }^{e}$ sugar must be avoided in diabetic or obese patients; ${ }^{f}$ protein-free products are dedicated to patients not on dialysis therapy and who need protein restriction but a high energy intake. ${ }^{29}$ Adapted from D'Alessandro C, Piccoli GB, Cupisti A. The "phosphorus pyramid": a visual tool for dietary phosphate management in dialysis and CKD patients. BMC Nephrol. 2015;16:9. ${ }^{29}$

serum phosphate levels compared with patients receiving $3 \mathrm{x}$ weekly sessions. ${ }^{36}$

Although phosphate removal by peritoneal dialysis has been less thoroughly studied, peritoneal phosphate clearance plays a role in achieving adequate phosphate homeostasis. Peritoneal creatinine clearance is a strong determinant of peritoneal phosphate clearance. In addition, peritoneal dialysis modality and membrane transport category (high, high average, low, average-low) have been independently associated with peritoneal phosphate clearance. Thus, peritoneal dialysis regimes with longer dwell times may help control hyperphosphatemia in lower transporters. ${ }^{37}$

While hemodiafiltration may be another attractive option, offering the combined benefits of diffusive hemodialysis with the advantages of large convective volumes, no additional benefits as compared with high-flux hemodialysis have been conclusively reported. ${ }^{38}$

\section{Phosphate-Binding Agents}

Phosphate binders reduce absorption of dietary phosphate in the gastrointestinal (GI) tract through the exchange of the anion phosphate with an active cation (carbonate, acetate, oxyhydroxide, and citrate) to form a nonabsorbable compound that is excreted in the feces. ${ }^{18}$ There are several phosphate binders currently available, and while they all lower phosphate levels to variable extents, each has unique advantages and disadvantages (Table 2). ${ }^{39}$

\section{Aluminum-Containing Phosphate Binders}

Aluminum-hydroxide has a high ionic binding affinity, low pill burden, and is relatively inexpensive. ${ }^{34}$ However, in the 1970s an increasing number of dialysis patients experienced severe aluminum intoxication. While dialysis fluid contamination by aluminum was identified as the culprit, intoxication with aluminum-containing phosphate binders was later reported in non-dialyzed patients. ${ }^{18}$ Sucralfate, which contains nearly half the aluminum content found in aluminum hydroxide, has demonstrated superior phosphate lowering efficacy and may be considered with close monitoring for fixed periods of time. ${ }^{40}$ However, because of the potential for toxicity, current KDIGO guidelines recommend against long-term use of aluminum-based phosphate binders. ${ }^{23}$

\section{Calcium Carbonate, Calcium Acetate, and Calcium Citrate}

Calcium-based binders are the most prescribed class of phosphate binder. However, a key concern with these agents is the 
Table 2 Key Characteristics of Phosphate Binders

\begin{tabular}{|c|c|c|c|c|}
\hline Type & Daily Dose & $\begin{array}{l}\text { Daily } \\
\text { Pill } \\
\text { Burden }\end{array}$ & Advantages & Disadvantages \\
\hline $\begin{array}{l}\text { Aluminum } \\
\text { hydroxide }\end{array}$ & No safe dose identified & - & Effective, inexpensive & $\begin{array}{l}\text { Potential for aluminum toxicity. Patient } \\
\text { requires careful monitoring }\end{array}$ \\
\hline $\begin{array}{l}\text { Calcium } \\
\text { acetate }\end{array}$ & $667 \mathrm{mg}$ & $\begin{array}{c}6-12 \\
\text { capsules }\end{array}$ & $\begin{array}{l}\text { Effective, potentially more so than } \\
\text { calcium carbonate with less calcium } \\
\text { absorption }\end{array}$ & $\begin{array}{l}\text { Potential for hypercalcemia; extra-skeletal } \\
\text { calcification; PTH suppression; GI side effects }\end{array}$ \\
\hline $\begin{array}{l}\text { Calcium } \\
\text { carbonate }\end{array}$ & $500-1250 \mathrm{mg}$ & $\begin{array}{c}3-6 \\
\text { tablets }\end{array}$ & Effective, inexpensive & $\begin{array}{l}\text { Potential for increased hypercalcemia - could } \\
\text { lead to vascular calcification; Gl side effects }\end{array}$ \\
\hline $\begin{array}{l}\text { Calcium } \\
\text { citrate }\end{array}$ & $\begin{array}{l}4000-6000 \mathrm{mg} \\
\text { (equivalent to } 250 \mathrm{mg} \\
\text { calcium per day) }\end{array}$ & 4-6 pills & Effective, inexpensive & $\begin{array}{l}\text { Enhancement of aluminum absorption; GI } \\
\text { side effects; not recommended in CKD }\end{array}$ \\
\hline $\begin{array}{l}\text { Sevelamer } \\
\text { hydrochloride }\end{array}$ & $800 \mathrm{mg}$ & $\begin{array}{c}6-12 \\
\text { capsules }\end{array}$ & $\begin{array}{l}\text { Effective; lipid-lowering effect; no } \\
\text { calcium }\end{array}$ & $\begin{array}{l}\text { Cost; GI side effects; potential development } \\
\text { of metabolic acidosis }\end{array}$ \\
\hline $\begin{array}{l}\text { Sevelamer } \\
\text { carbonate }\end{array}$ & $800 \mathrm{mg}$ & $\begin{array}{c}6-12 \\
\text { capsules }\end{array}$ & $\begin{array}{l}\text { Effective; lipid-lowering effect; no } \\
\text { calcium }\end{array}$ & Cost; GI side effects \\
\hline $\begin{array}{l}\text { Lanthanum } \\
\text { carbonate }\end{array}$ & $250-1000 \mathrm{mg}$ & $\begin{array}{l}\text { 3-6 } \\
\text { chewable } \\
\text { tablets }\end{array}$ & Effective; no calcium & $\begin{array}{l}\text { Cost; Gl side effects; systemic absorption } \\
\text { may be a concern due to potential for } \\
\text { accumulation }\end{array}$ \\
\hline $\begin{array}{l}\text { Sucroferric } \\
\text { oxyhydroxide }\end{array}$ & $500 \mathrm{mg}$ & $\begin{array}{l}2-6 \\
\text { chewable } \\
\text { tablets }\end{array}$ & $\begin{array}{l}\text { Effective; no calcium; does not lead to } \\
\text { iron overload }\end{array}$ & Cost; discolored feces; GI side effects \\
\hline
\end{tabular}

Note: Data from these studies. ${ }^{18,20,85-87}$

Abbreviations: CKD, chronic kidney disease; Gl, gastrointestinal.

development of a positive calcium balance which may aggravate vascular calcification and result in ectopic calcification which has been recognized as a major contributing factor for the increased risk of cardiovascular mortality in CKD patients. $^{23,41,42}$ It has therefore been recommended that the dose of calcium-based phosphate binders be limited to avoid calcium overload and possibly exacerbating vascular calcification, and that in patients not taking active vitamin $\mathrm{D}$ analogues, total elemental calcium intake be adjusted to maintain neutral calcium balance. .2,23 $^{2}$

\section{Lanthanum Carbonate}

Lanthanum carbonate has been shown to effectively lower phosphate levels with a daily pill burden of less than half compared with other phosphate binders. ${ }^{43,44}$ Moreover, in patients on hemodialysis randomized to lanthanum carbonate or calcium carbonate, lanthanum produced comparable reductions in phosphate levels without the hypercalcemia observed in the calcium carbonate group. ${ }^{45,46}$ In a multicenter randomized, double-blind, placebo-controlled trial lanthanum carbonate was also shown to effectively lower phosphate levels in nondialysis CKD stage 4 to 5 patients. ${ }^{47}$

Adverse events associated with lanthanum carbonate were reported in a systematic review and included vomiting, diarrhea, intradialytic hypotension, cramps, myalgia, and abdominal pain. ${ }^{46}$ Lanthanum carbonate also has a relatively low solubility and has been reported to accumulate in the bone with a 50-80-fold increase after 1 to 3 years of treatment in chronic dialysis patients. However, this has not been shown to be associated with clinical consequences. ${ }^{48-50}$

\section{Sevelamer}

Sevelamer hydrochloride was the first non-metalcontaining, nonabsorbable anion exchange binder. It is a crosslinked polymer that exchanges hydrogen chloride (sevelamer hydrochloride) or carbonate (sevelamer carbonate) for phosphate in the GI tract. ${ }^{51,52}$ 
Sevelamer has been shown to be effective in controlling hyperphosphatemia in both hemodialysis and peritoneal dialysis patients without inducing hypercalcemia. ${ }^{53-55}$ Sevelamer has also been associated with improvement in endothelial function and inflammatory markers. ${ }^{56}$ In addition, studies have suggested that sevelamer may prevent the accumulation of advanced glycation end-products. ${ }^{57}$ Moreover, in addition to chelating phosphate, sevelamer binds bile salts, thereby reducing serum total cholesterol and low-density lipoprotein (LDL) cholesterol in dialysis patients. ${ }^{58,59}$

However, there is a relatively high pill burden associated with sevelamer and important GI side effects, such as nausea and constipation, have been reported. As a resinbased binder, sevelamer can crystallize and result in GI mucosal injury. There have been reported cases of dysphagia, bowel obstruction, and perforation, with some requiring hospitalization and surgery. ${ }^{51}$

\section{Magnesium-Containing Phosphate Binders}

Magnesium-containing phosphate binders have been proposed as an alternative to calcium-containing phosphate binders to allow hemodialysis patients to reduce their calcium load. ${ }^{60}$ While the efficacy and safety of magnesium carbonate in combination with calcium acetate was noninferior to sevelamer in a Phase 3 RCT of 255 hemodialysis patients, in a 2-year, open-label RCT of patients with CKD stage 3-4 with risk factors for vascular calcification $(\mathrm{N}=125)$ magnesium oxide had no effect on serum phosphate levels. ${ }^{61,62}$

\section{Novel Phosphate Binding Agents and Approaches \\ Sucroferric Oxyhydroxide}

Sucroferric oxyhydroxide (SFOH) is an iron-based, noncalcium phosphate binder, approved for the control of serum phosphate levels in patients with ESKD on dialysis. ${ }^{63} \mathrm{SFOH}$ is a potent phosphate binder that offers patients a relatively low pill burden compared with other phosphate binders, which may increase adherence in the clinical setting. ${ }^{64}$

The efficacy and safety of SFOH was compared with that of sevelamer carbonate in an open-label, randomized, activecontrolled phase 3 study of hemodialysis and peritoneal dialysis patients with hyperphosphatemia. The study found that $\mathrm{SFOH}$ was non-inferior to sevelamer carbonate in lowering serum phosphate over 24 weeks. The mean pill burden remained greater with sevelamer carbonate ( 8.1 tablets/day) than with SFOH (3.1 tablets/day) over the course of the study. GI disorders were the most frequent adverse event in both treatment arms, observed in $45.1 \%$ of SFOH-treated patients and $33.6 \%$ of sevelamer carbonate-treated patients. ${ }^{65}$ A phase 3 extension study to assess the long-term efficacy and safety of SFOH found that serum phosphate levels were maintained to Week 52 and the tolerability of both treatments improved over time. $^{66}$

The long-term real-world effectiveness of SFOH in managing serum phosphate levels in hemodialysis patients over a 1-year period was assessed in a historical cohort analysis. Comparisons were made between the 91-day period prior to initiation of $\mathrm{SFOH}$ and the 4 consecutive 91-day intervals of SFOH treatment. The analysis revealed that 1 year after switching to SFOH therapy, the proportion of patients achieving target serum phosphate levels $(\leq 1.78$ $\mathrm{mmol} / \mathrm{L}[\leq 5.5 \mathrm{mg} / \mathrm{dL}])$ increased from $17.7 \%$ to $36.0 \%$ (P $<0.0001)$. Patients also experienced an average decrease of $50 \%$ from baseline in pill burden $(\mathrm{P}<0.0001) .{ }^{67}$

The real-world effectiveness of $\mathrm{SFOH}$ versus other phosphate binders in hemodialysis patients over 2 years was examined in another retrospective cohort study. The analysis comprised adult in-center hemodialysis patients prescribed 2 years of uninterrupted SFOH (maintenance) and patients who discontinued SFOH within 90 days of their first prescription and switched to other phosphate binder(s) for 2 years (discontinuation). The study found that, as compared to patients who discontinued SFOH, patients who maintained SFOH therapy achieved lower serum phosphate levels, were more likely to achieve target serum phosphate levels of $\leq 1.78 \mathrm{mmol} / \mathrm{L}(\leq 5.5 \mathrm{mg} / \mathrm{dL})$, were prescribed $\sim 50 \%$ fewer phosphate binder pills per day, and had lower annual hospitalization rates. ${ }^{68}$

\section{Tenapanor}

Tenapanor is a non-binder, sodium/hydrogen exchanger isoform 3 (NHE3) inhibitor. ${ }^{69}$ It is approved for the treatment of irritable bowel syndrome with constipation in adults and being studied as an inhibitor of dietary phosphate absorption. ${ }^{70}$

In a Phase 2 RCT assessing the effects of tenapanor on serum phosphate concentration in patients with hyperphosphatemia receiving hemodialysis, tenapanor provided dose-dependent reductions in serum phosphate levels. Diarrhea was the most common adverse event and more frequent with high doses of tenapanor. ${ }^{71}$ These findings were confirmed in a phase 3 RCT of twice-daily oral tenapanor in patients with hyperphosphatemia receiving 
hemodialysis. During the 8-week treatment period, tenapanor significantly decreased mean serum phosphate levels. Adverse events were largely limited to softened stool and an increase in bowel movement frequency, resulting from increased stool sodium and water content. ${ }^{72}$ The long-term safety and efficacy of tenapanor has also been reported in the 52-week phase 3 PHREEDOM study. ${ }^{73}$ Another recent report assessing tenapanor in dialysis patients with difficultto-control hyperphosphatemia suggested that this novel agent effectively lowers serum phosphate levels as both monotherapy and dual mechanism therapy (tenapanor + phosphate binder). ${ }^{74}$

\section{Nicotinamide}

Nicotinic acid is a water-soluble compound that can be metabolized to nicotinamide which has been shown to lower sodium-dependent intestinal phosphate absorption by reducing NaPi2b expression. ${ }^{75}$ Several studies in hemodialysis patients have suggested that nicotinamide treatment may lower serum phosphate levels, although patients in these studies experienced a high number of adverse events, including thrombocytopenia. ${ }^{76-78}$

It has also been hypothesized that the combination of a phosphate binder and nicotinamide may result in greater reductions in serum phosphate levels than either alone. ${ }^{79}$ To this end, COMBINE, a recent RCT, sought to assess whether the combination of lanthanum carbonate with nicotinamide is more effective than placebo or either compound alone. However, the study found that after a year, serum phosphate levels did not differ between the groups. Moreover, GI-related adverse events in the combination therapy arm limited treatment adherence. ${ }^{80}$

\section{Conclusion}

Hyperphosphatemia is common in patients with CKD and has been associated with an increased relative risk of hospitalization, cardiovascular events, and death. ${ }^{6-8,10,12}$ Strategies to manage hyperphosphatemia include dietary phosphate restriction, the dialytic removal of phosphate, and the use of phosphate binders. ${ }^{18}$ When considering hyperphosphatemia and its management, the authors suggest:

1. While awaiting the results of ongoing RCTs assessing the clinical utility of lowering serum phosphate levels, it is reasonable to continue to target lower phosphate levels given the currently available data demonstrating an association between hyperphosphatemia and morbidity and mortality in patients with $\mathrm{CKD} .^{8,10-12}$
2. Patient education should include general recommendations on the role of dietary phosphate restriction with emphasis on the hidden phosphate intake from phosphate additives in processed foods and carbonated beverages. Nutrient composition tables can be used to recommend food substitutions that can considerably reduce the daily intake of organic phosphate. $^{20,22}$ Guidance should also be offered on preparing foods at home, using methods such as boiling which may remove $\sim 50 \%$ of phosphate content. $^{22,81,82}$

3. Given that higher calcium concentrations have been linked to increased nonfatal cardiovascular events and mortality in adults with CKD, the dose of calciumbased phosphate binders should be restricted. ${ }^{23}$ In the opinion of the authors, previous KDOQI guidelines ${ }^{83}$ suggesting the total dose of elemental calcium provided by calcium-based phosphate binders not exceed $1,500 \mathrm{mg} /$ day seems reasonable.

4. The current KDIGO guidelines recommend that in adults with CKD receiving phosphate-lowering treatment, the dose of calcium-based phosphate binders be restricted. Further to this, we suggest that for patients with evidence of vascular calcification, consideration be given to use of non-calcium-based phosphate binders.

5. Pill burden and GI side effects such as abdominal bloating, diarrhea, and constipation, are significant impediments in patient adherence to phosphate binders. ${ }^{20}$ The multidisciplinary teams who see these patients should specifically address these concerns and consider switching phosphate binders to maximize adherence. Newer phosphate binders may offer lower pill burden and improved GI intolerance. ${ }^{63,64}$

In conclusion, the widespread treatment of hyperphosphatemia requires validation through completion of prospective randomized trials underway to ascertain whether and which method and degree of phosphate control results in optimal clinical outcomes in patients with CKD. In the interim, the decision and approach used to treat hyperphosphatemia should be based on the best available data, as well as patient needs and clinical judgment. The authors recommend that in CKD G5D patients with progressive and persistent hyperphosphatemia, phosphate lowering therapies be implemented. Clinicians should consider limiting the prescribed dose of calcium-based phosphate binders, especially in the setting of hypercalcemia, vascular or ectopic calcification or calciphylaxis. Furthermore, we recommend that patients with $\mathrm{CKD}$ receive nutritional education 
with respect to the dietary phosphate content of foods, including the bioavailability of phosphate depending on the protein source and the large contribution of inorganic phosphate found in food additives.

\section{Disclosure}

Dr Marisa Battistella reports honorarium from Otsuka, during the conduct of the study; speaking honorarium from Otsuka and from Pfizer, outside the submitted work. Mrs Roxanne Papineau reports personal fees from Otsuka, personal fees from AstraZeneca, outside the submitted work. Mrs Dianne Moseley reports the paper was sponsored by an unrestricted education grant from Otsuka Canada. The CPD Network designated liV Medical Education Agency to provide logistical support for the organization a scientific planning committee to develop educational material on the treatment of hyperphosphatemia. Honorarium was given through liV Medical Education Agency. The authors report no other conflicts of interest in this work.

\section{References}

1. Jamal SA, Fitchett D, Lok CE, Mendelssohn DC, Tsuyuki RT. The effects of calcium-based versus non-calcium-based phosphate binders on mortality among patients with chronic kidney disease: a meta-analysis. Nephrol Dial Transplant. 2009;24(10):3168-3174. doi:10.1093/ndt/gfp350

2. Sekercioglu N, Thabane L, Díaz Martínez JP, et al. Comparative effectiveness of phosphate binders in patients with chronic kidney disease: a systematic review and network meta-analysis. PLoS One. 2016;11(6):e0156891. doi:10.1371/journal.pone.0156891

3. Habbous S, Przech S, Acedillo R, Sarma S, Garg AX, Martin J. The efficacy and safety of sevelamer and lanthanum versus calcium-containing and iron-based binders in treating hyperphosphatemia in patients with chronic kidney disease: a systematic review and meta-analysis. Nephrol Dial Transplant. 2017;32(1):111-125. doi:10.1093/ndt/gfw312

4. Ruospo M, Palmer SC, Natale P, et al. Phosphate binders for preventing and treating chronic kidney disease-mineral and bone disorder (CKD-MBD). Cochrane Database Syst Rev. 2018;(8). doi:10.1002/ 14651858.CD006023.pub3

5. Jamal SA, Vandermeer B, Raggi P, et al. Effect of calcium-based versus non-calcium-based phosphate binders on mortality in patients with chronic kidney disease: an updated systematic review and meta-analysis. Lancet. 2013;382(9900):1268-1277. doi:10.1016/ S0140-6736(13)60897-1

6. Levin A, Bakris GL, Molitch M, et al. Prevalence of abnormal serum vitamin D, PTH, calcium, and phosphorus in patients with chronic kidney disease: results of the study to evaluate early kidney disease. Kidney Int. 2007;71(1):31-38. doi:10.1038/sj.ki.5002009

7. Kates DM, Sherrard DJ, Andress DL. Evidence that serum phosphate is independently associated with serum PTH in patients with chronic renal failure. Am J Kidney Dis. 1997;30(6):809-813. doi:10.1016/ s0272-6386(97)90086-x

8. Kestenbaum B, Sampson JN, Rudser KD, et al. Serum phosphate levels and mortality risk among people with chronic kidney disease. J Am Soc Nephrol. 2005;16(2):520-528. doi:10.1681/ ASN.2004070602
9. Waheed AA, Pedraza F, Lenz O, Isakova T. Phosphate control in end-stage renal disease: barriers and opportunities. Nephrol Dial Transplant. 2013;28(12):2961-2968. doi:10.1093/ndt/gft244

10. Block GA, Klassen PS, Lazarus JM, Ofsthun N, Lowrie EG, Chertow GM. Mineral metabolism, mortality, and morbidity in maintenance hemodialysis. J Am Soc Nephrol. 2004;15(8):2208-2218. doi:10.1097/01.ASN.0000133041.27682.A2

11. Tentori F, Blayney MJ, Albert JM, et al. Mortality risk for dialysis patients with different levels of serum calcium, phosphorus, and PTH: the Dialysis Outcomes and Practice Patterns Study (DOPPS). Am J Kidney Dis. 2008;52(3):519-530. doi:10.1053/j. ajkd.2008.03.020

12. Slinin Y, Foley RN, Collins AJ. Calcium, phosphorus, parathyroid hormone, and cardiovascular disease in hemodialysis patients: the USRDS waves 1, 3, and 4 study. J Am Soc Nephrol. 2005;16 (6):1788-1793. doi:10.1681/ASN.2004040275

13. Block GA, Wheeler DC, Persky MS, et al. Effects of phosphate binders in moderate CKD. J Am Soc Nephrol. 2012;23 (8):1407-1415. doi:10.1681/ASN.2012030223

14. St Peter WL, Liu J, Weinhandl E, Fan Q. A comparison of sevelamer and calcium-based phosphate binders on mortality, hospitalization, and morbidity in hemodialysis: a secondary analysis of the Dialysis Clinical Outcomes Revisited (DCOR) randomized trial using claims data. Am J Kidney Dis. 2008;51(3):445-454. doi:10.1053/j.ajkd.2007.12.002

15. Wald R, Rabbat CG, Girard L, et al. Two phosphAte taRGets in End-stage renal disease Trial (TARGET): a randomized controlled trial. Clin J Am Soc Nephrol. 2017;12(6):965-973. doi:10.2215/ CJN.10941016

16. ClinicalTrials.gov. HiLo: pragmatic trial of higher vs lower serum phosphate targets in patients undergoing hemodialysis - full text view - ClinicalTrials.gov. Available from: https://clinicaltrials.gov/ct2/ show/NCT04095039. Accessed November 26, 2020.

17. ClinicalTrials.gov. Pragmatic randomised trial of high or standard PHosphAte targets in end-stage kidney disease (PHOSPHATE) full text view - ClinicalTrials.gov. Available from: https:/clinical trials.gov/ct2/show/NCT03573089. Accessed November 26, 2020.

18. Barreto FC, Barreto DV, Massy ZA, Drüeke TB. Strategies for phosphate control in patients with CKD. Kidney Int Rep. 2019;4 (8):1043-1056. doi:10.1016/j.ekir.2019.06.002

19. Cozzolino M, Ketteler M, Wagner CA. An expert update on novel therapeutic targets for hyperphosphatemia in chronic kidney disease: preclinical and clinical innovations. Expert Opin Ther Targets. 2020;24(5):477-488. doi:10.1080/14728222.2020.1743680

20. Umeukeje EM, Mixon AS, Cavanaugh KL. Phosphate-control adherence in hemodialysis patients: current perspectives. Patient Prefer Adherence. 2018;12:1175-1191. doi:10.2147/PPA.S145648

21. Vervloet MG, Sezer S, Massy ZA, Johansson L, Cozzolino M, Fouque D. The role of phosphate in kidney disease. Nat Rev Nephrol. 2017;13(1):27-38. doi:10.1038/nrneph.2016.164

22. Ikizler TA, Burrowes JD, Byham-Gray LD, et al. KDOQI clinical practice guideline for nutrition in CKD: 2020 update. Am J Kidney Dis. 2020;76(3):S1-S107. doi:10.1053/j.ajkd.2020.05.006

23. Ketteler M, Block GA, Evenepoel P, et al. Executive summary of the 2017 KDIGO chronic kidney disease-mineral and bone disorder (CKD-MBD) guideline update: what's changed and why it matters. Kidney Int. 2017;92:26-36. doi:10.1016/j.kint.2017.10.001

24. Sullivan CM, Leon JB, Sehgal AR. Phosphorus-containing food additives and the accuracy of nutrient databases: implications for renal patients. J Ren Nutr. 2007;17(5):350-354. doi:10.1053/j. jrn.2007.05.008

25. Rufino M. Is it possible to control hyperphosphataemia with diet, without inducing protein malnutrition? Nephrol Dial Transplant. 1998;13(90003):65-67. doi:10.1093/ndt/13.supp1_3.65

26. Lynch KE, Lynch R, Curhan GC, Brunelli SM. Prescribed dietary phosphate restriction and survival among hemodialysis patients. Clin J Am Soc Nephrol. 2011;6(3):620-629. doi:10.2215/CJN.04620510 
27. Shinaberger CS, Greenland S, Kopple JD, et al. Is controlling phosphorus by decreasing dietary protein intake beneficial or harmful in persons with chronic kidney disease? Am J Clin Nutr. 2008;88 (6):1511-1518. doi:10.3945/ajcn.2008.26665

28. Moreira AC, Carolino E, Domingos F, Gaspar A, Ponce P, Camilo ME. Nutritional status influences generic and disease-specific quality of life measures in haemodialysis patients. Nutr Hosp. 2013;28(3):951-957. doi:10.3305/ nh.2013.28.3.6454

29. D'Alessandro C, Piccoli GB, Cupisti A. The "phosphorus pyramid": a visual tool for dietary phosphate management in dialysis and CKD patients. BMC Nephrol. 2015;16:9. doi:10.1186/1471-2369-16-9

30. Kuhlmann MK. Phosphate elimination in modalities of hemodialysis and peritoneal dialysis. BPU. 2010;29(2):137-144. doi:10.1159/ 000245640

31. Ramirez JA, Emmett M, White MG, et al. The absorption of dietary phosphorus and calcium in hemodialysis patients. Kidney Int. 1986;30(5):753-759. doi:10.1038/ki.1986.252

32. Gutzwiller J-P, Schneditz D, Huber AR, Schindler C, Gutzwiller F, Zehnder CE. Estimating phosphate removal in haemodialysis: an additional tool to quantify dialysis dose. Nephrol Dial Transplant. 2002;17(6):1037-1044. doi:10.1093/ndt/17.6.1037

33. Kalantar-Zadeh K. Patient education for phosphorus management in chronic kidney disease. Patient Prefer Adherence. 2013;7:379-390. doi:10.2147/PPA.S43486

34. Rastogi A, Bhatt N, Rossetti S, Beto J. Management of hyperphosphatemia in end-stage renal disease: a new paradigm. $J$ Ren Nutr. 2021;31:21-34. doi:10.1053/j.jrn.2020.02.003

35. Locatelli F, Del Vecchio L, Violo L, Pontoriero G. Phosphate binders for the treatment of hyperphosphatemia in chronic kidney disease patients on dialysis: a comparison of safety profiles. Expert Opin Drug Saf. 2014;13(5):551-561. doi:10.1517/14740338.2014.907791

36. Daugirdas JT, Chertow GM, Larive B, et al. Effects of frequent hemodialysis on measures of CKD mineral and bone disorder. $J \mathrm{Am}$ Soc Nephrol. 2012;23(4):727-738. doi:10.1681/ASN.2011070688

37. Badve SV, Zimmerman DL, Knoll GA, Burns KD, McCormick BB. Peritoneal phosphate clearance is influenced by peritoneal dialysis modality, independent of peritoneal transport characteristics. Clin $J$ Am Soc Nephrol. 2008;3(6):1711-1717. doi:10.2215/ CJN.00190108

38. Locatelli F, Carfagna F, Del Vecchio L, La Milia V. Haemodialysis or haemodiafiltration: that is the question. Nephrol Dial Transplant. 2018;33(11):1896-1904. doi:10.1093/ndt/gfy035

39. Health Canada. Drug product database: access the database. March 18, 2001. Available from: https://www.canada.ca/en/health-canada /services/drugs-health-products/drug-products/drug-product-database. html. Accessed November 3, 2020.

40. Roxe DM, Mistovich M, Barch DH. Phosphate-binding effects of sucralfate in patients with chronic renal failure. Am J Kidney Dis. 1989;13(3):194-199. doi:10.1016/s0272-6386(89)80052-6

41. Shanahan CM, Crouthamel MH, Kapustin A, Giachelli CM. Arterial calcification in chronic kidney disease: key roles for calcium and phosphate. Circ Res. 2011;109(6):697-711. doi:10.1161/ CIRCRESAHA.110.234914

42. London GM, Guérin AP, Marchais SJ, Métivier F, Pannier B, Adda $\mathrm{H}$. Arterial media calcification in end-stage renal disease: impact on all-cause and cardiovascular mortality. Nephrol Dial Transplant. 2003;18(9):1731-1740. doi:10.1093/ndt/gfg414

43. Vemuri N, Michelis MF, Matalon A. Conversion to lanthanum carbonate monotherapy effectively controls serum phosphorus with a reduced tablet burden: a multicenter open-label study. $B M C$ Nephrol. 2011;12:49. doi:10.1186/1471-2369-12-49

44. Wilson RJ, Keith MS, Preston P, Copley JB. The real-world dose-relativity of sevelamer hydrochloride and lanthanum carbonate monotherapy in patients with end-stage renal disease. Adv Ther. 2013;30(12):1100-1110. doi:10.1007/s12325-013-0077-5
45. Toida T, Fukudome K, Fujimoto S, et al. Effect of lanthanum carbonate vs. calcium carbonate on serum calcium in hemodialysis patients: a crossover study. Clin Nephrol. 2012;78(3):216-223. doi: $10.5414 / \mathrm{cn} 107257$

46. Zhang C, Wen J, Li Z, Fan J. Efficacy and safety of lanthanum carbonate on chronic kidney disease-mineral and bone disorder in dialysis patients: a systematic review. BMC Nephrol. 2013;14:226. doi:10.1186/1471-2369-14-226

47. Takahara Y, Matsuda Y, Takahashi S, Shigematsu T, et al. Efficacy and safety of lanthanum carbonate in pre-dialysis CKD patients with hyperphosphatemia: a randomized trial. Clin Nephrol. 2014;82 (3):181-190. doi:10.5414/cn108269

48. Black T, Philips G, Burbridge R. Pharmacobezoar in a patient on an oral phosphate binder. Gastrointest Endosc. 2013;77(3):511-512. doi:10.1016/j.gie.2012.11.002

49. Hutchison AJ, Barnett ME, Krause R, et al. Lanthanum carbonate treatment, for up to 6 years, is not associated with adverse effects on the liver in patients with chronic kidney disease Stage 5 receiving hemodialysis. Clin Nephrol. 2009;71(3):286-295.

50. Spasovski GB, Sikole A, Gelev S, et al. Evolution of bone and plasma concentration of lanthanum in dialysis patients before, during 1 year of treatment with lanthanum carbonate and after 2 years of follow-up. Nephrol Dial Transplant. 2006;21(8):2217-2224. doi:10.1093/ndt/gfl146

51. sanofi-aventis Canada Inc. PrRENAGEL ${ }^{\circledR}$ : sevelamer hydrochloride tablets product monograph. 2018.

52. sanofi-aventis Canada Inc. PrRENVELA ${ }^{\circledR}$ : sevelamer carbonate tablets product monograph. 2019.

53. Bleyer AJ, Burke SK, Dillon M, et al. A comparison of the calcium-free phosphate binder sevelamer hydrochloride with calcium acetate in the treatment of hyperphosphatemia in hemodialysis patients. Am J Kidney Dis. 1999;33(4):694-701. doi:10.1016/s02726386(99)70221-0

54. Qunibi WY, Hootkins RE, McDowell LL, et al. Treatment of hyperphosphatemia in hemodialysis patients: the Calcium Acetate Renagel Evaluation (CARE Study). Kidney Int. 2004;65(5):1914-1926. doi:10.1111/j.1523-1755.2004.00590.x

55. Evenepoel P, Selgas R, Caputo F, et al. Efficacy and safety of sevelamer hydrochloride and calcium acetate in patients on peritoneal dialysis. Nephrol Dial Transplant. 2009;24(1):278-285. doi:10.1093/ndt/gfn488

56. Chennasamudram SP, Noor T, Vasylyeva TL. Comparison of sevelamer and calcium carbonate on endothelial function and inflammation in patients on peritoneal dialysis. J Ren Care. 2013;39(2):82-89. doi:10.1111/j.1755-6686.2013.12009.x

57. Gregório PC, Favretto G, Sassaki GL, et al. Sevelamer reduces endothelial inflammatory response to advanced glycation end products. Clin Kidney J. 2018;11(1):89-98. doi:10.1093/ckj/sfx074

58. Braunlin W, Zhorov E, Guo A, et al. Bile acid binding to sevelamer $\mathrm{HCl}$. Kidney Int. 2002;62(2):611-619. doi:10.1046/j.15231755.2002.00459.x

59. Burke SK, Dillon MA, Hemken DE, Rezabek MS, Balwit JM. Metaanalysis of the effect of sevelamer on phosphorus, calcium, PTH, and serum lipids in dialysis patients. Adv Ren Replace Ther. 2003;10 (2):133-145. doi:10.1053/jarr.2003.50016

60. Spiegel DM, Farmer B, Smits G, Chonchol M. Magnesium carbonate is an effective phosphate binder for chronic hemodialysis patients: a pilot study. J Ren Nutr. 2007;17(6):416-422. doi:10.1053/j.jrn.2007.08.005

61. Sakaguchi Y, Hamano T, Obi Y, et al. A randomized trial of magnesium oxide and oral carbon adsorbent for coronary artery calcification in predialysis CKD. J Am Soc Nephrol. 2019;30(6):1073-1085. doi:10.1681/ASN.2018111150

62. de Francisco ALM, Leidig M, Covic AC, et al. Evaluation of calcium acetate/magnesium carbonate as a phosphate binder compared with sevelamer hydrochloride in haemodialysis patients: a controlled randomized study (CALMAG study) assessing efficacy and tolerability. Nephrol Dial Transplant. 2010;25(11):3707-3717. doi:10.1093/ndt/ gfq292 
63. Otsuka Canada Pharmaceutical Inc. Velphoro (sucroferric oxyhydroxide) product monograph. 2019.

64. Sprague SM, Floege J. Sucroferric oxyhydroxide for the treatment of hyperphosphatemia. Expert Opin Pharmacother. 2018;19 (10):1137-1148. doi:10.1080/14656566.2018.1491548

65. Floege J, Covic AC, Ketteler M, et al. A Phase III study of the efficacy and safety of a novel iron-based phosphate binder in dialysis patients. Kidney Int. 2014;86(3):638-647. doi:10.1038/ki.2014.58

66. Floege J, Covic AC, Ketteler M, et al. Long-term effects of the iron-based phosphate binder, sucroferric oxyhydroxide, in dialysis patients. Nephrol Dial Transplant. 2015;30(6):1037-1046. doi:10.1093/ndt/gfv006

67. Kendrick J, Parameswaran V, Ficociello LH, et al. One-year historical cohort study of the phosphate binder sucroferric oxyhydroxide in patients on maintenance hemodialysis. J Ren Nutr. 2019;29 (5):428-437. doi:10.1053/j.jrn.2018.11.002

68. Coyne DW, Ficociello LH, Parameswaran V, et al. Sucroferric oxyhydroxide in maintenance hemodialysis: a retrospective, comparative cohort study. Kid Med. 2020;2(3):307-316. doi:10.1016/j. xkme.2020.01.009

69. Labonté ED, Carreras CW, Leadbetter MR, et al. Gastrointestinal inhibition of sodium-hydrogen exchanger 3 reduces phosphorus absorption and protects against vascular calcification in CKD. J Am Soc Nephrol. 2015;26(5):1138-1149. doi:10.1681/ASN.2014030317

70. Knight Therapeutics Inc. Tenapanor product monograph; 2020. Available from: https://pdf.hres.ca/dpd_pm/00058277.PDF Accessed December 17, 2020.

71. Block GA, Rosenbaum DP, Leonsson-Zachrisson M, et al. Effect of tenapanor on serum phosphate in patients receiving hemodialysis. $J$ Am Soc Nephrol. 2017;28(6):1933-1942. doi:10.1681/ ASN.2016080855

72. Block GA, Rosenbaum DP, Yan A, Chertow GM. Efficacy and safety of tenapanor in patients with hyperphosphatemia receiving maintenance hemodialysis: a randomized phase 3 trial. J Am Soc Nephrol. 2019;30(4):641-652. doi:10.1681/ASN.2018080 832

73. Chertow G, Yang Y, Rosenbaum D. Long-term safety and efficacy of tenapanor for the control of serum phosphorus in patients with CKD on dialysis. J Am Soc Nephrol. 2020. Available form: https://www. asn-online.org/education/kidneyweek/2020/program-abstract.aspx? controlId=3450189. Accessed August 3, 2021.

74. Rosenbaum D, Yang Y. Efficacy of tenapanor for the control of serum phosphorus in patients with CKD on dialysis: novel mechanism of action allows for both monotherapy and dual-mechanism approach. Am J Kidney Dis. 2020;75:627.
75. Katai K, Tanaka H, Tatsumi S, et al. Nicotinamide inhibits sodium-dependent phosphate cotransport activity in rat small intestine. Nephrol Dial Transplant. 1999;14(5):1195-1201. doi:10.1093/ndt/ 14.5.1195

76. Takahashi Y, Tanaka A, Nakamura T, et al. Nicotinamide suppresses hyperphosphatemia in hemodialysis patients. Kidney Int. 2004;65 (3):1099-1104. doi:10.1111/j.1523-1755.2004.00482.x

77. Cheng SC, Young DO, Huang Y, Delmez JA, Coyne DW. A randomized, double-blind, placebo-controlled trial of niacinamide for reduction of phosphorus in hemodialysis patients. Clin J Am Soc Nephrol. 2008;3(4):1131-1138. doi:10.2215/CJN.04211007

78. Lenglet A, Liabeuf S, El Esper N, et al. Efficacy and safety of nicotinamide in haemodialysis patients: the NICOREN study. Nephrol Dial Transplant. 2017;32(5):870-879. doi:10.1093/ndt/ gfw042

79. Yeung WCG, Toussaint ND, Badve SV. Dual inhibition of gastrointestinal phosphate absorption: more questions than answers. $J \mathrm{Am}$ Soc Nephrol. 2019;30(6):909-910. doi:10.1681/ASN.2019040333

80. Ix JH, Isakova $\mathrm{T}$, Larive $\mathrm{B}$, et al. Effects of nicotinamide and lanthanum carbonate on serum phosphate and fibroblast growth factor-23 in CKD: the COMBINE trial. J Am Soc Nephrol. 2019;30 (6):1096-1108. doi:10.1681/ASN.2018101058

81. Cupisti A, Comar F, Benini O, et al. Effect of boiling on dietary phosphate and nitrogen intake. J Ren Nutr. 2006;16(1):36-40. doi:10.1053/j.jrn.2005.10.005

82. Ando S, Sakuma M, Morimoto Y, Arai H. The effect of various boiling conditions on reduction of phosphorus and protein in meat. J Ren Nutr. 2015;25(6):504-509. doi:10.1053/j.jrn.2015.05.005

83. Massry SG, Coburn JW, Chertow GMet al. K/DOQI clinical practice guidelines for bone metabolism and disease in chronic kidney disease. Am J Kidney Dis. 2003;42(4 Suppl 3):i-S201.

84. Li J, Wang L, Han M, et al. The role of phosphate-containing medications and low dietary phosphorus-protein ratio in reducing intestinal phosphorus load in patients with chronic kidney disease. Nutr Diabetes. 2019;9(1):14. doi:10.1038/s41387-019-0080-2

85. Floege J. Phosphate binders in chronic kidney disease: a systematic review of recent data. J Nephrol. 2016;29(3):329-340. doi:10.1007/ s40620-016-0266-9

86. Floege J. Phosphate binders in chronic kidney disease: an updated narrative review of recent data. J Nephrol. 2020;33(3):497-508. doi:10.1007/s40620-019-00689-w

87. Carfagna F, Del Vecchio L, Pontoriero G, Locatelli F. Current and potential treatment options for hyperphosphatemia. Expert Opin Drug Saf. 2018;17(6):597-607. doi:10.1080/14740338.2018.1476487
The International Journal of Nephrology and Renovascular Disease is an international, peer-reviewed open-access journal focusing on the pathophysiology of the kidney and vascular supply. Epidemiology, screening, diagnosis, and treatment interventions are covered as well as basic science, biochemical and immunological studies. The manuscript management system is completely online and includes a very quick and fair peer-review system, which is all easy to use. Visit http://www.dovepress.com/testimonials.php to read real quotes from published authors. 